\title{
Clinical description of 41 Brazilian patients with oculo-auriculo- -vertebral dysplasia
}

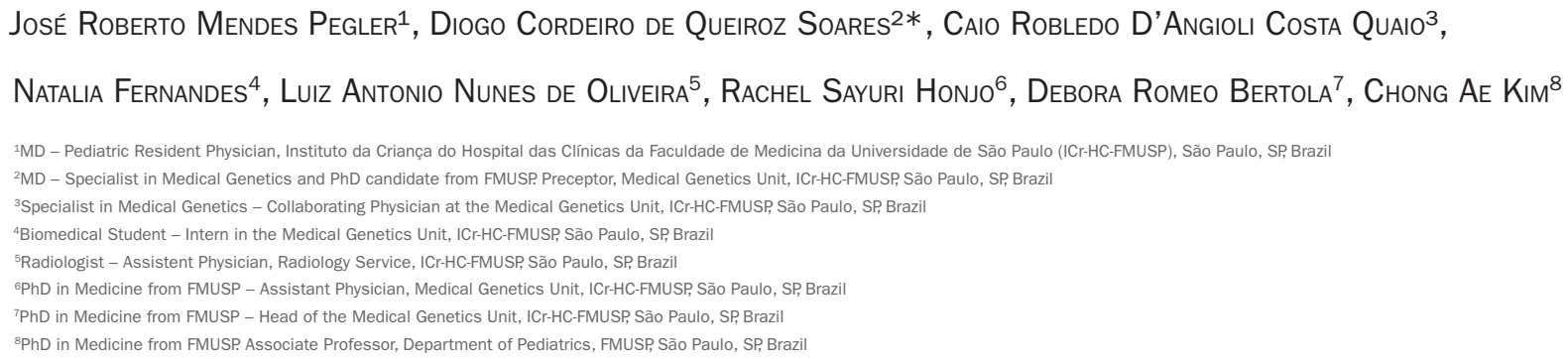

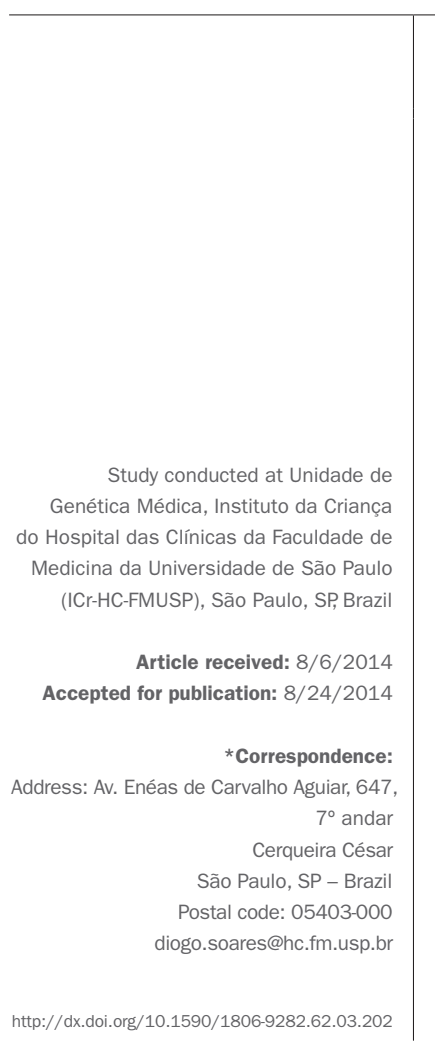

\section{SUMMARY}

Objective: To describe the most prominent clinical features of a cohort of patients with oculo-auriculo-vertebral (OAV) dysplasia in Brazil.

Method: A review of medical records of patients with diagnosis of OAV from 1990 to 2010 was performed in a medical genetics center.

Results: 41 patients were included in the study. Their average age at diagnosis was $2 \mathrm{y} 10 \mathrm{mo}(34,4 \pm 48,8$ months $)$ and the female proportion was $53.7 \%$. Mean maternal age at patient's birth was $28.5 y$ (min: 17 , max: $46 y$ ) for mothers and $31.4 y$ (min: 21, max: 51y) for fathers. Most patients (97.5\%) had auricular involvement, with facial manifestation in $90.2 \%$, spinal in $65.9 \%$, ocular in $53.7 \%, 36.6 \%$ with cardiovascular involvement, $29.3 \%$ urogenital, and $17 \%$ of the cases with central nervous system (CNS) involvement. The classic OAV triad was present in only $34 \%$. All patients except one had concomitant problems in other organs or systems.

Conclusion: Since the diagnosis of OAV dysplasia relies only on a comprehensive medical evaluation, it is imperative that clinicians be aware of the most common presentation of the syndrome. Once suspected, every patient should undergo a complete medical evaluation of multiple systems including complementary exams. Treatment of these patients is based on surgical correction of malformations and rehabilitation.

Keywords: Goldenhar syndrome, facial asymmetry, craniofacial abnormalities.

\section{INTRODUCTION}

The Goldenhar syndrome was described in 1845 by Carl Ferdinand von Arlt and recognized as a clinical entity in 1952 by Maurice Goldenhar who described it in a child, as reported Salvitti et al. ${ }^{1}$ It has been known as first branchial arch syndrome, Gorlin's syndrome and hemifacial microsomia (OMIM 164210), but currently it is best known as oculo-auriculo-vertebral (OAV) dysplasia, a nomenclature given by Gorlin et al. ${ }^{2}$ and Sugar. ${ }^{3}$

Its prevalence has been estimated at about one case per 5,600 to 26,550 births ${ }^{4-6}$ with greater involvement of males than females (in a ratio of about $3: 2)^{7}$ The cases are mostly sporadic, but families with autosomal recessive or auto- somal dominant inheritance have been described; 8,9 thus, the hypothesis that there is no kind of genetic factor involved that would influence susceptibility to the disease has been ruled out. ${ }^{10}$ In this regard, reports of monozygotic twins, ${ }^{11}$ both dichorionic and monochorionic, ${ }^{12}$ discordant for the disease have been made, suggesting a correlation with a multifactorial inheritance pattern.

Moreover, there is evidence in the literature indicating that ingestion of certain drugs, such as thalidomide, retinoic acid, tamoxifen and cocaine during pregnancy can be related to the development of this condition. Other factors have been suggested as etiological factors include maternal diabetes, viral infections (e.g. rubella and influenza) and 
the abuse of alcohol during pregnancy as well. ${ }^{13-15} \mathrm{Mou}-$ noud et al. reported a case of OAV dysplasia in a child whose mother had a history of hypervitaminosis A. It is known that daily doses of vitamin A higher than 25,000 IU have teratogenic effects. This teratogen has harmful effects in the formation of neural crest cells, which are essential for the formation of the pharyngeal arches. ${ }^{16,17}$

Affected individuals may present: malar and/or mandibular hypoplasia, hypoplasia of the facial muscles, microtia, preauricular tags and outer ear dysplasia, hemivertebrae and hypoplasia of cervical thoracic or lumbar vertebrae, epibulbar dermoids, microphthalmia, cleft palate and/or lip, cardiac, kidney or central nervous system (CNS) anomalies. ${ }^{2}$ In addition, there are reports on the association of OAV dysplasia with other conditions, such as genitourinary, ${ }^{18,19}$ cardiovascular,,$^{14,20}$ or psychiatric ${ }^{21,22}$ changes, and obstructive sleep apnea. ${ }^{23}$ However, due to clinical variability, some patients have minimal manifestations, predominantly facial asymmetry and dysplasia of the auricular pavilion. ${ }^{2}$

Based on the above, and considering the importance of the topic due to prevalence, wide spectrum of clinical manifestations and the lack of studies that describe a significant number of patients suffering from OAV dysplasia in our midst, we describe a case series of patients diagnosed with OAV dysplasia followed in our service over the past 20 years.

\section{Method}

The sample consisted of individuals followed in the Medical Genetics Unit at Instituto da Criança, Hospital das Clínicas, Faculdade de Medicina da Universidade de São Paulo (ICr-HC-FMUSP), diagnosed with OAV dysplasia from 1990 to 2010. This study was approved by the Ethics Committee for Research Project Analysis - CAPPesq of HC-FMUSP (No. 0667-07).

Patients included in the study were those with normal G-banding karyotype and involvement of at least two of the following sites: 1) mouth, skull and face, 2) eyes, 3) ears and 4) vertebrae. This approach was consistent with that adopted by Strömland et al. (2007).$^{12}$ Individuals with chromosomal abnormalities or incomplete medical records were excluded from the study.

We conducted a retrospective analysis, and collected data on clinical manifestations (ear, face, spine, eyes and more), demographics (gender, date of birth, age at first consultation, and age of parents) and results of additional tests. The affected side (right, left or bilateral) was that where microtia or facial microsomia was located, similarly to the method adopted by Rollnick et al. (1987). ${ }^{24}$

\section{Results}

Among the 41 patients studied, 19 (46.3\%) were male and $22(53.7 \%)$ female. The mean age at first consultation was 2 years and 10 months ( $34.4 \pm 48.8$ months). The mean age of parents at the birth of the child in cases where information was available (39/41 patients) was $28.5 \pm 6.9$ years for the mothers and 31.4 \pm 7.4 years for the fathers.

With regard to clinical manifestations, $97.5 \%$ of the patients had some degree of ear involvement, $90.2 \%$ facial, $65.9 \%$ vertebral, and $53.7 \%$ ocular. $89 \%$ of children had involvement of other organs. The classic OAV triad was present in only $34 \%$ ( 15 children). All patients except one had concomitant problems in other organs or systems.

\section{Facial manifestations}

Facial abnormalities were observed in $90.2 \%$ (37/41) of patients. Of these, $83.8 \%(31 / 37)$ had some degree of hemifacial microsomia. In $46 \%$ (17/37) of the cases, change in facial expression was observed, suggesting some degree of facial paralysis. We also found that $14 \%(6 / 37)$ of the cases had cleft palate and/or lip and 7\% (3/37) had ocular hypertelorism.

\section{Ocular manifestations}

From the classic triad of changes described as OAV dysplasia, ocular changes were less frequent in our series, with about $53.7 \%$ (22/41) of patients presenting some involvement. Epibulbar dermoids or dermoid cysts were seen in $45.4 \%$ (10/22), representing the vast majority in the group of eye diseases, followed by the finding of epicanthus, present in $22.7 \%(5 / 22)$ and other epibulbar tumors, present in $13.6 \%(3 / 22)$. Other ocular manifestations found in our series at a lower prevalence ( 1 or 2 cases) are: coloboma, changes in the lacrimal gland, anophthalmia and amaurosis.

\section{Auricular manifestations}

In terms of location, $30 \%(12 / 40)$ of patients had involvement limited to the right side, 30\% (12/40) had abnormalities only in the left side, and 40\% (16/40) were affected bilaterally. The most commonly found malformation was that of auricular dysplasia to varying degrees in $73 \%(30 / 41)$. The presence of preauricular tags occurred in 51.2\% (21/41) of cases. In $24.4 \%$ (10/41) of patients, these two manifestations were simultaneous. In 31.7\% (13/41) of cases, some degree of functional hearing loss was reported. Other changes described, by order of prevalence, are: auditory canal stenosis in $14.6 \%(6 / 41)$, auditory canal agenesis in $12.2 \%$ (5/41), abnormal implantation of the pinna in $9.8 \%(4 / 41)$, and recurrent acute otitis media in $7.3 \%(3 / 41)$. 
Vertebral manifestations

$65.9 \%(27 / 41)$ of the patients had vertebral abnormalities. Of these, spinal axis changes were found most often including marked kyphosis and/or scoliosis in $48.2 \%$ $(13 / 27)$ of cases. Localized vertebral involvements were also prevalent, including the finding of hemivertebrae in $37 \%(10 / 27)$ cases, most often in the thoracic segment with $25 \%(7 / 27)$ patients affected. Block or fused vertebrae were diagnosed in 33\% (9/27) of cases, with greater involvement of the cervical spine, affected in $77.7 \%$ (7/9) of patients, as well as the presence of incomplete fusion of vertebral arches in $14.8 \%$ (4/27) of the patients. Other reports included: sacral dimples in $22 \%(6 / 27)$ of patients, spina bifida in $14.8 \%$ (4/27), and transitional vertebrae in $14.8 \%(4 / 27)$.

\section{Other systemic manifestations Cardiovascular system}

Cardiovascular involvement was found in 36.6\% (15/41) of the patients. The spectrum is quite heterogeneous, but the most frequent changes were communications between heart chambers, which were present in $36.6 \%$ of the patients with cardiac involvement. Interatrial communication was responsible for $40 \%(6 / 15)$ of the cases, and ventricular septal defects for $33.3 \%$ (5/15) of the cases. Complex congenital heart disease were seen in $26.7 \%$ (4/15) patients, the most common being the tetralogy of Fallot, present in $50 \%(2 / 4)$ of cases. Persistent arterial duct was found in $20 \%(3 / 15)$ of the patients.

\section{Urogenital system}

In our sample, $29.3 \%(12 / 41)$ of patients showed abnormalities in the urinary tract, of which $41.7 \%(5 / 12)$ had concomitant change in the cardiovascular system. Among the abnormalities found, pelvic kidneys and unilateral renal agenesis were the most prevalent occurrences, both present in $41.7 \%(5 / 12)$ patients each. Of note, among patients diagnosed with pelvic kidney, 80\% (4/5) had ipsilateral ear involvement. Other changes less frequently observed (1 or 2 cases) were pyelocaliceal ectasia, pyeloureteral duplication, vesicoureteral reflux and hypospadias.

\section{Central nervous system}

$17 \%(7 / 41)$ of the patients had CNS changes, especially expansion of the cerebral ventricles, found in $43 \%$ (03/07) of cases. $28.6 \%$ (2/7) of these cases had dysgenesis of the corpus callosum associated with ventriculomegaly, and $14.3 \%(1 / 7)$ showed absence of the septum pellucidum associated with ventriculomegaly. Occipital encephalocele associated with posterior parietal meningoencephalocele was less frequent alteration found in one patient.

\section{Discussion}

OAV dysplasia is a well-defined entity, characterized by unilateral or bilateral craniofacial anomalies, to a variable degree, involving the first and second branchial arches, and vertebral and eye abnormalities. Clinically, it varies from an isolated microtia, with or without mandibular hypoplasia, to a more complex phenotype involving skeletal, cardiac, renal, lung and CNS disorders. ${ }^{24,25}$

As previously mentioned, much has been speculated about the etiological and pathogenic mechanisms that lead to the development of OAV dysplasia. In this sense, several studies have been performed to identify genetic changes that may be related to the phenotype displayed by patients with OAV, but so far such correlation could not be established. ${ }^{26}$

Our results reveal that 21 (48\%) patients were male and $23(52 \%)$ were female, a proportion similar to that found in a study conducted in the city of Bauru, state of São Pau$10,{ }^{27}$ and different from that observed in other studies that found male predominance with a ratio of $3: 2{ }^{7}$

Regarding the therapeutic approach, in less complex cases interventions vary according to the age and systemic involvement and are mainly intended to improve esthetics. In patients with mandibular hypoplasia, reconstructive surgery can be performed using bone grafts taken from the ribs and, in some instances, bone stretching. In cases where there is cleft lip and/or palate, surgical correction is usually performed followed by the use of orthodontic devices after correction of mandibular defects.

Reconstructive surgery to correct auricular malformation is usually performed at the age of 6 to 8 years. In patients with milder involvement, mandibular reconstruction surgery can be performed in early adolescence. Epibulbar dermoids must be removed surgically. Structural ocular anomalies and those of the outer ear should be corrected by plastic surgeons.

\section{Conclusion}

It is important to emphasize that individuals with OAV dysplasia often have psychosocial difficulties caused by stigma. Thus, the participation of a multidisciplinary team is crucial so that patients can be addressed globally for proper support. In general, the prognosis is good, especially in cases without systemic involvement. More severe cases of OAV dysplasia can affect many aspects of a patient's life, and many require interventions shortly after birth. ${ }^{2,14}$ 
TABLE 1 Type and frequency of changes observed in patients with OAV dysplasia.

\begin{tabular}{|c|c|c|}
\hline Type of change & $\mathbf{n}$ & $\%$ \\
\hline Auricular & $40 / 41$ & 97.5 \\
\hline Dysplastic pinna & $30 / 40$ & 75 \\
\hline Preauricular tags & $21 / 40$ & 52.5 \\
\hline Hearing loss & $13 / 40$ & 32.5 \\
\hline Auditory canal stenosis & $6 / 40$ & 15 \\
\hline Abnormal implantation of the ears & $4 / 40$ & 10 \\
\hline Recurrent otitis media & $3 / 40$ & 7.5 \\
\hline Facial & $37 / 41$ & 90.2 \\
\hline Hemifacial microsomia & $31 / 37$ & 83.8 \\
\hline Change in facial expression & $17 / 37$ & 46 \\
\hline Cleft lip and/or palate & $6 / 37$ & 16.2 \\
\hline Ocular hypertelorism & $3 / 37$ & 8.1 \\
\hline Vertebral & $27 / 41$ & 65.9 \\
\hline Kyphosis/scoliosis & $13 / 27$ & 48.2 \\
\hline Hemivertebrae & $10 / 27$ & 37 \\
\hline Block/fused vertebrae & $9 / 27$ & 33.3 \\
\hline Sacral dimple & $6 / 27$ & 22.2 \\
\hline Spina bifida & $4 / 27$ & 14.8 \\
\hline Incomplete fusion of vertebral arches & $4 / 27$ & 14.8 \\
\hline Transitional vertebrae & $4 / 27$ & 14.8 \\
\hline Ocular & $22 / 41$ & 53.7 \\
\hline Epibulbar dermoids & $10 / 22$ & 45.4 \\
\hline Epicanthus & $5 / 22$ & 22.7 \\
\hline Other epibulbar tumors & $3 / 22$ & 13.6 \\
\hline Coloboma & $1 / 22$ & 4.6 \\
\hline Anophthalmia & $1 / 22$ & 4.6 \\
\hline Amaurosis & $1 / 22$ & 4.6 \\
\hline Cardiovascular & $15 / 41$ & 36.6 \\
\hline Interatrial communication & $6 / 15$ & 40 \\
\hline Interventricular communication & $5 / 15$ & 33.3 \\
\hline Complex cardiopathy & $4 / 15$ & 26.7 \\
\hline Persistent arterial duct & $3 / 15$ & 20 \\
\hline Urogenital & $12 / 41$ & 29.3 \\
\hline Pelvic kidney & $5 / 12$ & 41.7 \\
\hline Renal agenesis & $5 / 12$ & 41.7 \\
\hline Pyelocaliceal ectasia & $1 / 12$ & 8.3 \\
\hline Pyeloureteral duplication & $1 / 12$ & 8.3 \\
\hline Vesicoureteral reflux & $1 / 12$ & 8.3 \\
\hline Hypospadias & $2 / 12$ & 16.6 \\
\hline Central nervous system & $7 / 41$ & 17 \\
\hline Expansion of the cerebral ventricles & $3 / 7$ & 43 \\
\hline Dysgenesis of the corpus callosum & $2 / 7$ & 28.6 \\
\hline Absence of the septum pellucidum & $1 / 7$ & 14.3 \\
\hline $\begin{array}{l}\text { Occipital encephalocele with posterior } \\
\text { parietal meningoencephalocele }\end{array}$ & $1 / 7$ & 14.3 \\
\hline
\end{tabular}

\section{Resumo}

Displasia óculo-aurículo-vertebral: aspectos clínicos de 41 pacientes brasileiros

Objetivo: descrever os principais achados clínicos de uma coorte de pacientes com a displasia óculo-aurículo-vertebral (OAV).

Método: revisão de prontuários médicos dos pacientes com diagnóstico de OAV no período de 1990 a 2010, acompanhados em um centro de genética médica.

Resultados: foram incluídos no estudo 41 pacientes. A média de idade ao diagnóstico foi de 2 anos e 10 meses $(34,4 \pm 48,8$ meses) e a proporção de pacientes do sexo feminino foi de $53,7 \%$. A média de idade dos pais ao nascimento do paciente foi de $28,5 \pm 6,9$ anos para as mães e $31,4 \pm 7,4$ anos para os pais. A maioria dos indivíduos (97,5\%) possuía acometimento auricular, $90,2 \%$ tinham manifestações faciais, $65,9 \%$, vertebrais, $53,7 \%$, oculares, $36,6 \%$, cardiovasculares, $29,3 \%$, urogenitais e $17 \%$, no sistema nervoso central. Além disso, $34 \%$ dos pacientes apresentavam a tríade clássica óculo-aurículo-vertebral, e todos os pacientes exceto um apresentavam concomitantemente problemas em outros órgãos ou sistemas.

Conclusão: já que o diagnóstico desta entidade é eminentemente clínico, é imprescindível que os médicos das mais diversas especialidades conheçam os achados mais frequentes na OAV. Diante de um paciente com suspeita diagnóstica, deve ser realizada avaliação detalhada de outros órgãos, tanto clínica como por meio de exames complementares. $O$ tratamento é baseado na correção cirúrgica das malformações e na reabilitação.

Palavras-chave: síndrome de Goldenhar, assimetria facial, anormalidades craniofaciais.

\section{References}

1. Salvitti C, Azulay RD, Heringer ML, Almeida de Faria LA. [Oculo-auriculovertebral dysplasia: presentation of a case and attempt at organizing the symptomatology]. Rev Ass Med Bras. 1978; 24(5):160-2.

2. Gorlin RL. Branchial arch and oro-acral disorders. In: Gorlin JJ, Cohen Jr MM, Hennekam RC (eds.). Syndromes of the head and neck. London: Oxford University Press, 2001. p.790-97.

3. Sugar HS. The oculoauriculovertebral dysplasia syndrome of Goldenhar. Am J Ophthalmol. 1966; 62(4):678.

4. Grabb WC. The first and second branchial arch syndrome. Plast Reconstr Surg. $1965 ; 36(5): 485-508$.

5. Stoll C, Roth MP, Dott B, Bigel T. Discordance for skeletal and cardiac defect in monozygotic twins. Acta Genet Med Gemellol. 1984; 33(3):501-4.

6. Melnick M. The etiology of external ear malformations and its relation to abnormalities of the middle ear, inner ear and other organ systems. Birth Defects Orig Artic Ser. 1980; 16(4):303-31.

7. Cohen Jr MM, Rollinck BR, Kaye CI. Oculoauriculoveretbral spectrum: an updated critique. Cleft Palate J. 1989; 26(4):276-86. 
8. Pearson A. Developmental anatomy of the ear. In: English M (ed.). Otolaryngology. New York: Harper and Row, 1978. p.1-68.

9. Scholtz AW, Fish III JH, Kammen-Jolly K, Ichiki H, Hussl B, Kreczy A, et al Goldenhar's syndrome: congenital hearing deficit of conductive or sensorineural origin? Temporal bone histopathologic study. Otol Neurotol 2001; 22(4):501-5

10. Phelps PD, Lloyd GA, Poswillo DE. The ear deformities in craniofacial microsomia and oculo-auriculo-vertebral dysplasia. J Laryngol Otol. 1983; 97(11):995-1005

11. Bisdas S, Lenarz M, Lenarz $\mathrm{T}$, Becker $\mathrm{H}$. Inner ear abnormalities in patients with Goldenhar syndrome. Otol Neurotol. 2005; 26(3):398-404.

12. Strömland K, Miller M, Sjögreen L, Johansson M, Joelsson B-ME, Billstedt E, et al. Oculo-auriculo-vertebral spectrum: associated anomalies, functional deficits and possible development risk factors. Am J Med Genet. 2007; 143A(12):1317-25

13. Mehta B, Nayak C, Savant S, Amladi S. Goldenhar syndrome with unusal features. Indian J Venerol Dermatol Leprol. 2008; 74(3):254-6.

14. Nakajima H, Goto G, Tanaka N, Ashiya H, Ibukiyama C. Goldenhar syndrome associated with various cardiovascular malformations. Jpn Circ J. 1998; 62(8):617-20.

15. Das A, Ray B, Das D. A case of Goldenhar-Gorlin syndrome with unusual association of hypoplastic thumb. Indian J Ophthamol. 2008; 56(2):150-2.

16. Mounoud RL, Klein D, Weber F. [A case of Goldenhar syndrome: acute vitamin A intoxication in the mother during pregnancy]. J Genet Hum. $1975 ; 23(2): 135-54$

17. Maj V, Col R. Golden-har syndrome. Mjafi. 2000; 56:231-2.
18. Ishitoya S, Arai Y, Okubo K, SuzukiY. Left retrocaval ureter associated with the Goldenhar syndrome (branchial arch syndrome). J Urol. 1997; 158(2):572-3.

19. Ritchey ML, Norbeck J, Huang C, Keating MA, Bloom DA. Urologic manifestations of Goldenhar syndrome. Urology. 1994; 43(1):88-91.

20. Kumar A, Friedman JM, Taylor GP, Patterson MWH. Pattern of cardiac malformation in oculoauriculovertebral spectrum. Am J Med Genet. 1993; 46(3):423-6.

21. Brieger P, Bartel-Friederich S, Haring A, Marneros A. Oculo-auriculo-vertebral spectrum disorder (Goldenhar "syndrome") coexisting with schizophreniform disorder. J Neurol Neurosurg Psychiatry. 1998; 65(1):135-6.

22. Lleonart M, Sarduy A, Gil M, Lois L. Displasia oculoauriculovertebral o síndrome de Goldenhar: estudio multidisciplinario de un caso clínico. Rev Cubana Oftalmol. 2001; 14(1):42-6

23. Hoch B, Hochban W. Four-year-old girl with Goldenhar-sequence and severe obstructive sleep apnea, symptoms, diagnosis and therapy. Int J Pediatr Otorhinolaryngol. 1998; 43(3):277-81.

24. Rollnick BR, Kaye CI, Nagatoshi K, Hauck W, Martin AO. Oculo auriculovertebral dysplasia and variants: phenotypic characteristic of 294 patients. Am J Med Genet. 1987; 26(2):361-75.

25. Kelberman D, Tyson J, Chandler DC, McInerney AM, Slee J, Albert D, et al. Hemifacial microsomia: progress in understanding the genetic basis of a complex malformation syndrome. Hum Genet. 2001; 109(6):638-45.

26. Brosco KC, Zorzetto NL, Costa AR. [Audiology profile in patients with Goldenhar's syndrome]. Rev Bras Otorrinolaringol. 2004; 70(5):645-9.

27. Smith DW. Síndromes de malformações congênitas: aspectos genéticos, embriológicos e clínicos. 3.ed. São Paulo: Manole, 1985. 